\section{Seductive Details in the Flipped Classroom: The Impact of Interesting but Educationally Irrelevant Information on Student Learning and Motivation}

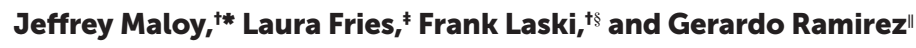

${ }^{\dagger}$ Department of Life Sciences Core Education, "Department of Psychology, and \$Department of Molecular, Cell, and Developmental Biology, University of California, Los Angeles, Los Angeles, CA 90095; "Department of Educational Psychology, Ball State University, Muncie, IN 47306

\begin{abstract}
In this study, we assessed the impact of providing students with short video clips highlighting the relevance of material they are learning in the genetics classroom to their everyday lives. These interesting but non-learning objective oriented clips, referred to as "seductive details," have been studied extensively in laboratory contexts. In laboratory studies, seductive details have been shown to actually decrease learning, leading some to recommend that any information not directly pertaining to academic learning outcomes be removed from education materials. We aimed to uncover effects of seductive details in an actual college course, in a manner divorced from the confounding variation introduced by instructor-level differences in personality and lecture styles. Our results show that, in a flipped-classroom environment, seductive details do not harm students' content attainment, interest, or perceived learning, but they are memorable. Students with high background knowledge of genetics reported greater learning after watching videos containing seductive details than students who watched equivalent videos without seductive details, but there was no difference in quiz scores between the groups. These results contradict some of the major effects observed throughout decades of studies conducted in artificial psychology laboratory environments and highlight possible affective benefits of instructors using seductive details.
\end{abstract}

\section{INTRODUCTION}

A core challenge of undergraduate science, technology, engineering, and mathematics (STEM) education in the United States is retention of historically marginalized students in STEM majors (President's Council of Advisors on Science and Technology, 2012; Hughes, 2018). For example, underrepresented minority (URM) and first-generation students who begin as STEM majors are much more likely to change majors than non-URM/first-generation students in STEM majors or URM/first-generation students in humanities and social sciences fields (Sork et al., 2015). There are institutional (e.g., availability of advising and mentoring programs), cognitive (e.g., background knowledge), and motivational (e.g., interest, self-efficacy, and perceived relevance of course material) factors that explain part of the story for the high dropout rate in STEM (Cromley et al., 2016). But strategies to retain underrepresented students are not yet fully meeting this challenge. In this study, we ask whether momentary enhancements of science material, using seductive details during lectures, can improve course outcomes for URM and first-generation students.

\section{Improving Interest in STEM}

Perhaps intuitively, many instructors recognize the significance of student interest, and they are taught to develop ways to enhance this psychological state of focused
Daron Barnard, Monitoring Editor Submitted Jan 9, 2019; Revised Apr 29, 2019; Accepted May 6, 2019

CBE Life Sci Educ September 1, 2019 18:ar42 DOI:10.1187/cbe.19-01-0004

*Address correspondence to: Jeffrey Maloy (jmaloy@ucla.edu).

(C) 2019 J. Maloy et al. CBE-Life Sciences Education @ 2019 The American Society for Cell Biology. This article is distributed by The American Society for Cell Biology under license from the author(s). It is available to the public under an Attribution-Noncommercial-Share Alike 3.0 Unported Creative Commons License (http://creativecommons.org/licenses/ by-nc-sa/3.0)

"ASCB®" and "The American Society for Cell Biology ${ }^{\circledR}$ " are registered trademarks of The American Society for Cell Biology. 
attention, persistence, and engagement. This recommendation is empirically founded, as research demonstrates that higher domain interest is associated with greater attention, task persistence, and effort (Ainley et al., 2002; Hidi and Renninger, 2006). Students' domain interest as first-year college students even predicts major retention, grades, and course taking 7 years later (Harackiewicz et al., 2008). Of course, promoting domain interest is the end goal of a long and complicated process.

For most students, the interest that they have for a domain begins with instructors attempting to promote situational interest. Education theorists like John Dewey have long taught the importance of catching and holding interest (Dewey, 1913). More recently, the four-phase model for interest development argues that repeated situations that catch a student's interest can, over time, develop into a more enduring disposition by promoting engagement with target content (Hidi and Renninger, 2006). Hence, contemporary theories for enhancing interest place a high premium on external supports that deliberately scaffold student interest throughout a lesson, particularly for content that students may find initially less interesting.

There exist a variety of context-specific approaches for promoting situational interest. For instance, instructors can vary the novelty and complexity of the content to match students' background knowledge and interests (Berlyne, 1970); present students with content-relevant images that create surprise or awe (Arcand et al., 2010; Stahl and Feigenson, 2015; Valdesolo et al., 2017); use problem-based learning with authentic dilemmas (Belland et al., 2013); provide context rendering content useful to students' daily lives (i.e., utility value; Eccles et al., 1983); and incorporate hands-on activities, group work, and active-learning techniques (Palmer, 2009; Freeman et al., 2014). A widely implemented technique involves the use of seductive details: engaging and concrete information that is tangential to the learning objectives of a lesson. In the current study, we explore the effect of seductive details on motivation and achievement in a flipped STEM classroom.

\section{The Paradox of Seductive Details in Classroom Instruction} Seductive details may consist of the use of humor in the classroom, non sequitur images, memes, or other references and anecdotes that loosely connect course material to culturally relevant or otherwise interesting topics (Downs et al., 1988; Cooper et al., 2018). The goal of using seductive details is not to present content in an interesting manner, but rather to supplement content with alluring information that is superficially relevant to the lesson content. Instructors often view seductive details as a way to help bring attention back to content, particularly for lesson segments that students find uninteresting or highly abstract. For example, when discussing the lac operon as an example of the regulation of gene expression in bacteria, an instructor might stray briefly from activities directly relevant to the learning outcomes (e.g., "Describe how the lac repressor and catabolite repressor protein regulate expression of the lac operon") to capture students' interest with the following story:

One real-world application of the lac operon is its importance to a favorite snack: yogurt! Without the lac operon, bacteria wouldn't be able to turn milk into yogurt. Long ago, ancient people probably stumbled upon yogurt by accident: it's what happened when they left milk out in warm weather. You probably wouldn't want to drink sun-warmed milk, but some brave human tried it and discovered what many people love today: the milk ferments into a rich tangy yogurt. History even says that Ghenghis Khan sustained himself and his armies on yogurt made from the milk of their horses as they were off conquering civilizations and spreading their empire.

Additional examples of seductive details that may appear in a biology classroom can be found in Supplemental Table S1.

To be sure, the use of seductive details is something that instructors and students commonly think enhances instruction (Yue and Bjork, 2017), which explains why their use is commonplace (Mayer et al., 2008). Yet their effectiveness has been studied extensively in laboratory contexts. Surprisingly, a variety of laboratory studies suggest that, when seductive details are used, their inclusion does promote interest but can actually reduce learning as measured by recall performance and knowledge transfer performance (Harp and Mayer, 1998; Rey, 2012). In a typical laboratory experiment, participants are presented with expository text passages or learning modules in which the seductive details (in the form of captions, pictures, or both) are either included in or excluded from the content. One recent meta-analysis concluded that the use of seductive details in laboratory settings is associated with a small to medium negative effect size (Rey, 2012).

The fact that laboratory evidence reveals that the use of seductive details reduces learning has led to the recommendation that any information not directly pertaining to academic learning outcomes be removed from education materials (Harp and Mayer, 1998; Harp and Maslich, 2005). However, more recent work reveals seductive details can actually help learning when the instructional context creates a low cognitive load for students (Park et al., 2011, 2015a). Additionally, another study demonstrated that, when the laboratory setting is altered to look more like a real-world classroom setting by increasing the stakes of learning, the negative effect of seductive details was abrogated, leading to either similar or enhanced learning outcomes for students provided with seductive details compared with those not provided with seductive details (Fries et al., 2019). These observations led us to question the pertinence of previous lab studies to the more nuanced longitudinal experience of students in the STEM classroom.

Additionally, though laboratory studies are useful for gaining insight into instructional strategies that impact specific student outcomes in highly controlled environments, these studies sometimes fail to replicate their effects when applied to actual classroom environments (Mitchell, 2012). This shortcoming likely stems at least in part from the increased complexity of a classroom environment compared with the carefully controlled environment of a psychology lab. Determining whether a specific educational intervention is effective in the classroom requires testing in a large group of students across many classes, and often with multiple independent instructors. Because of the inherent heterogeneity introduced by this requirement for rigor in classroom studies, it can be difficult or impossible to maintain the same level of control and consistency afforded by laboratory studies on educational interventions. 


\section{Use of Seductive Details in a Flipped Classroom Environment}

The past decade has seen a rapid expansion in the use of blended learning models that combine digital media with classroom instruction for STEM students (Johnson et al., 2015). The use of completely or partially online learning modules is thought to confer various benefits to students, including increased accessibility, decreased textbook costs, and enhanced academic outcomes (Garrison and Kanuka, 2004; Arfield et al., 2013; Sarıtepeci and Çakır, 2015). Additionally, digital media modules blended with face-to-face classroom instruction provide an intriguing tool to education researchers in the form of a highly controlled video platform in which to test educational interventions that have been difficult to examine in traditional classrooms. For this reason, the potential of video modules in education research has been compared with the use of wind tunnels in the development of the airplane: much like the wind tunnel allows for the rapid, controlled testing of various aircraft designs, video learning modules provide an opportunity to test a number of promising educational interventions in large groups of students across multiple classes and instructors using a consistent and controlled delivery platform (Stigler and Givvin, 2017).

In this study, we aimed to uncover the effect of including seductive details in an undergraduate genetics course in a manner divorced from the inevitable confounding variation introduced by instructor-level differences in personality and lecture styles. If previous laboratory results apply in the context of a classroom, then we should expect that the inclusion of seductive details in video lectures will increase interest but ultimately distract student attention and harm learning. However, if professors' anecdotal accounts of the benefits of seductive details more accurately represent the impact of such details on student learning in a classroom environment, then we should expect that the inclusion of seductive details will improve classroom learning as measured by end-of-video quizzes. In line with anecdotal accounts from educators and recent literature in this area (Fries et al., 2019), we surmised that the inclusion of seductive details would generally be beneficial for improving actual performance as well as perceived learning.

We also examined whether the inclusion of seductive details could enhance situational interest in the material and improve students' perceptions of the content utility value. Recent intervention research out of the field of psychology finds that relatively small changes in instruction can result in significant increases in students' interest in and perceived relevance of course material (Harackiewicz et al., 2016; Casad et al., 2018). For instance, even briefly mentioning some of the possible utility of math techniques led to an enhancement in classroom performance (Hulleman et al., 2010).

Both interest and perceived relevance have been shown to correlate to each other as well as with performance and retention in STEM majors (Zusho et al., 2003; Hurtado et al., 2010). Furthermore, interventions targeting interest and perceived relevance have produced promising results, demonstrating an improvement in course performance and short-term retention for low socioeconomic status, first-generation, and URM students specifically in the life sciences (Hulleman et al., 2010). In brief, we attempted to systematically examine whether the use of seductive details can change both performance and proximal motivational predictors of STEM learning and participation.
TABLE 1. Demographics of control and experimental groups ${ }^{\mathrm{a}}$

\begin{tabular}{lccc}
\hline & \multicolumn{2}{c}{ SeD group } & \\
\cline { 2 - 3 } Variable & Control & SeD & Total \\
\hline Gender, $n$ (\%) & & & \\
$\quad$ Male & $114(29.3)$ & $123(33.7)$ & $237(31.4)$ \\
$\quad$ Female & $274(70.4)$ & $240(65.8)$ & $514(68.2)$ \\
$\quad$ Other & $1(0.3)$ & $2(0.5)$ & $3(0.4)$ \\
URM status, $n$ (\%) & & & \\
$\quad$ Non-URM & $309(79.4)$ & $294(80.5)$ & $603(80.0)$ \\
$\quad$ URM & $80(20.6)$ & $71(19.5)$ & $151(20.0)$ \\
First-generation status, $n(\%)$ & & \\
$\quad$ Non-first generation & $238(61.2)$ & $217(59.5)$ & $455(60.3)$ \\
$\quad$ First generation & $147(37.8)$ & $141(38.6)$ & $288(38.2)$ \\
Prior knowledge, $n$ (\%) & & & \\
$\quad$ Low & $238(61.2)$ & $216(59.2)$ & $454(60.2)$ \\
$\quad$ High & $151(38.8)$ & $149(40.8)$ & $300(39.8)$ \\
\hline
\end{tabular}

apercentages within control and seductive detail (SeD) groups are shown in parentheses alongside absolute numbers. $N=754$.

\section{METHODS}

Groupings

In two large undergraduate genetics courses $(N=754)$, students were randomized into two groups using a between-subjects design. Demographics of these randomized groups are shown in Table 1 . The control group received standard lecture videos for the entirety of the study, with no seductive details presented. The treatment group (who were presented with seductive details) received videos with equivalent genetics information plus short seductive detail video segments interspersed throughout the videos. A total of two clips with seductive detail, each averaging around 1 minute in length, were included in the video lecture material for the seductive detail group for each class session. These seductive detail clips were presented for each lecture through the first 4 weeks of the course (until the first midterm). In total, for the duration of the intervention, the control group received 7 hours and 41 minutes of lecture videos, and the experimental group received 7 hours and 58 minutes of lecture videos. For both groups, preclass lecture videos consisted of between one and four videos averaging 23 minutes in length for a total of 20 preclass lecture videos. This chunking of lecture videos into shorter clips ensured that all students paused occasionally while watching preclass videos.

\section{Seductive Details}

To assess the impact of seductive details on student motivation and learning, we recorded a series of video clips containing seductive details about comparatively dry genetics concepts and interspersed these seductive detail clips into required video lectures that students were tasked with watching before class. These details were designed to be highly interesting, but irrelevant to the prescribed learning outcomes of the course. For instance, during a unit on Drosophila genetics, we presented students in the seductive details condition with an anecdote about how fruit flies (Drosophila) that are rejected by potential mating partners increase their consumption of alcohol. The clip was simply intended to catch the interest of students and does not actually teach anything relevant to course learning outcomes 
about Drosophila genetics. A complete list of seductive details provided to students in video lectures is provided in Supplemental Table S1. These video clips were presented as visually abrupt interruptions to the normal video lecture content, with a change in the video background and text indicating the beginning of "Genetics Applied Around Us" segments (Supplemental Figure S1). At the beginning of the first video lecture assigned for the course, students were told that these segments narrated by a different instructor than the primary course instructor were only for the students' interest and that students would not be required to remember any of the information in the clips for the course.

\section{Video Surveys and Quizzes}

Before each class session, students were required to watch two to four preclass videos totaling approximately 45 minutes of content delivery time. After watching these videos, students were asked to fill out a survey about their experiences watching the videos. Each survey included items asking students to indicate their interest in the video and the perceived relevance of the material presented in the video to their own lives. The surveys also asked students to rate on a scale of 1-10 how much they thought they had learned from the videos. Students were also given the option to respond to open-ended questions regarding their favorite parts of the videos and the content that they felt they were most likely to remember at a much later date.

After taking the video surveys, students were required to complete a preclass video quiz pertaining to the material presented in these videos. Preclass video quizzes consisted of four questions each for a total possible score of 2 points, with grades assigned based on accuracy. These quizzes asked students to apply knowledge and problem-solving strategies from video lessons to solve new genetics problems. Of the questions asked in video quizzes during the intervention period, $92 \%$ were categorized as "apply"-level questions according to Bloom et al.'s (1956) taxonomy, with the remainder classified as "remember"-level questions. Examples of video quiz questions can be found in Supplemental Table S2. Video quizzes totaled 30 points out of 500 possible course points. Due to the nature of online video quizzes and a course policy allowing quiz retakes, there is no way to ascertain whether students were sharing answers or completing the quizzes independently.

\section{Pre- and Postcourse Surveys}

Students were asked to participate in precourse, postintervention, and postcourse surveys. Items on these surveys were designed to assess student interest in genetics (Hulleman and Harackiewicz, 2009), utility value associated with genetics (Hulleman and Harackiewicz, 2009; Canning and Harackiewicz, 2015), and preferences for video lessons that include "just the facts" versus lessons that also include interesting, but irrelevant anecdotes. In the precourse survey, students were also asked to self-report their prior knowledge pertaining to eight course learning objectives aligned with the weeks in which the intervention was carried out (Table 2). Students were split into low and high prior knowledge groups based on a median split, with a total of $39.8 \%$ of students described as having a high level of prior background knowledge of the material covered in the genetics course.

\section{Data Analysis}

Statistics analyses were performed using IBM SPSS Statistics. For all hypothesis tests performed in this study, a $p$ value of 0.05 was considered to be the threshold for statistical significance. Between-group comparisons were performed using two-tailed independent-sample $t$ tests. Effect sizes were calculated using partial eta-squared. A chi-square test of linear-by-linear association was performed to determine whether differences existed in seductive detail recall between prior knowledge groups. Violin plots were made using BoxPlotR (Spitzer et al., 2014). Other graphs and images were made using Microsoft Excel and ggplot2 in R.

\section{RESULTS \\ Seductive Details Do Not Affect Learning or Motivation Overall}

Given the wealth of previous psychology laboratory data suggesting the detrimental effects of seductive details on student learning, we anticipated that the inclusion of seductive details might decrease quiz scores while increasing student interest and perceived relevance of the course material. However, we find that the inclusion of seductive details had no aggregate effect on any of these measures. Video quiz scores were high and statistically the same in both groups, with an average of $1.67 \pm 0.27$ (SD) points in the control

TABLE 2. Survey items used to assess self-reported prior knowledge $\mathrm{a}^{\mathrm{a}}$

\begin{tabular}{|c|c|c|c|}
\hline & Mean & SeD & $\begin{array}{l}\text { Item-total } \\
\text { correlation }\end{array}$ \\
\hline I can calculate the probability that an individual in a pedigree has a particular genotype. & 2.75 & 1.18 & 0.55 \\
\hline $\begin{array}{l}\text { I can explain how independent assortment of alleles during meiosis can lead to new combinations } \\
\text { of alleles of unlinked genes. }\end{array}$ & 2.67 & 1.15 & 0.61 \\
\hline I can discuss Beadle and Tatum’s "One gene-one enzyme" hypothesis. & 2.11 & 1.38 & 0.35 \\
\hline I can design a screen for isolating antibiotic resistance mutants and auxotrophic revertants. & 1.50 & 0.925 & 0.62 \\
\hline $\begin{array}{l}\text { I can design a bacteriophage cross that will allow the calculation of genetic map distance between } \\
\text { two genes. }\end{array}$ & 1.34 & 0.77 & 0.59 \\
\hline
\end{tabular}

aScale ranged from 1 (not at all true of me) to 5 (completely true of me). Cronbach's alpha $=0.84 . N=742$. 


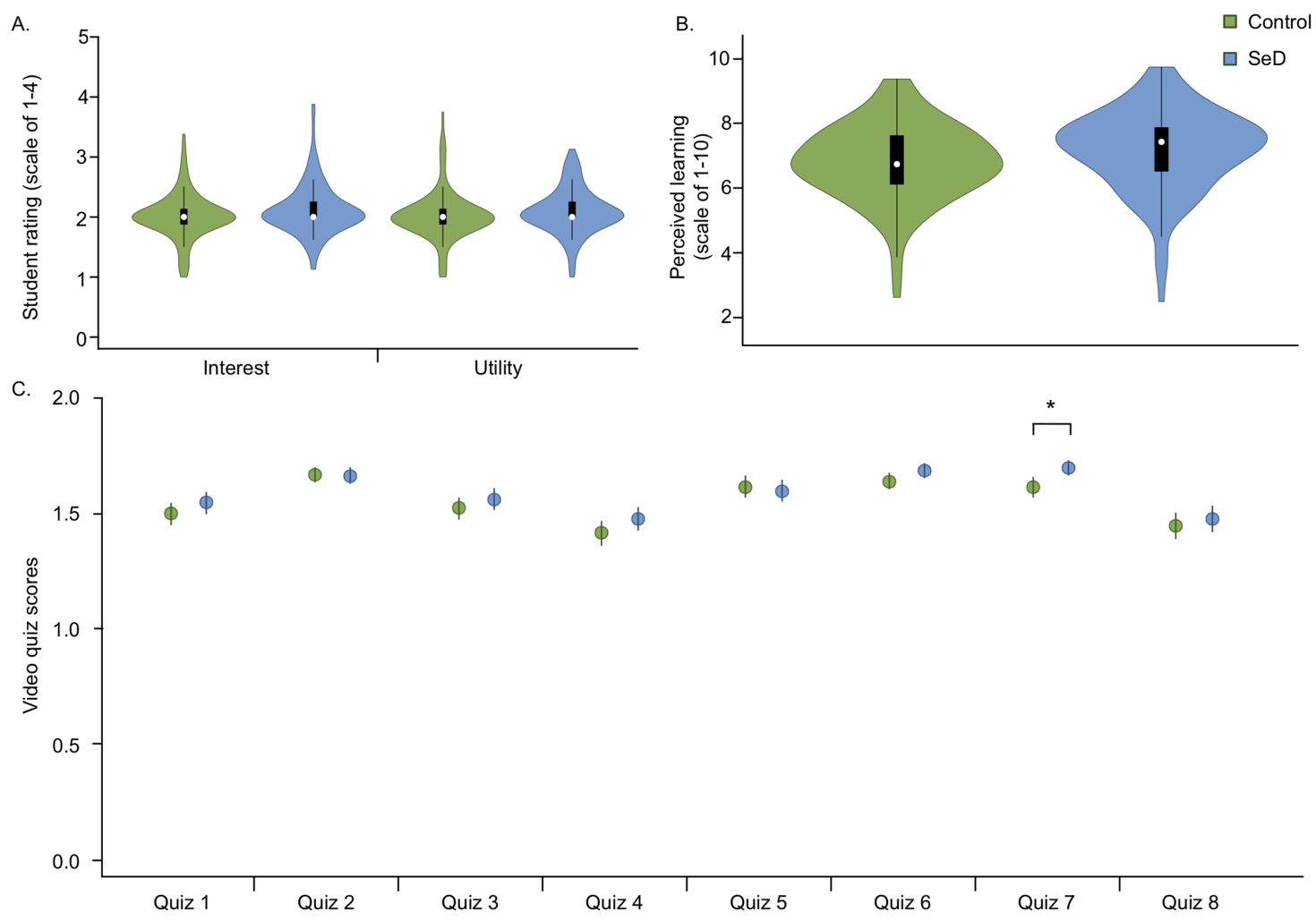

FIGURE 1. (A) Violin plots of reported interest in video lectures and perceived relevance of video lecture material to students' lives or future plans. White circles show the medians; box limits indicate the 25th and 75th percentiles as determined by R software; whiskers extend 1.5 times the interquartile range from the 25th and 75th percentiles; polygons represent density estimates of data and extend to extreme values. (B) Violin plots of average self-reported perceptions of learning from video lectures. (C) Average video quiz scores for each lesson. Dots indicate mean score for each quiz; whiskers indicate the $95 \%$ confidence interval. $n=353,346,359,356,360,362,365,359,357,355$, $360,360,364,352,349,353$ sample points. Significant differences $(p<0.05)$ are denoted with an asterisk. SeD, seductive details. $*, p=0.004$.

group and $1.68 \pm 0.28(\mathrm{SD})$ in the seductive detail group (Figure 1A). Students in the seductive detail group scored slightly higher on quiz 7, but the effect size was minimal and not observed with other quizzes. Similarly, student perception of video content was similar between groups, with no difference observed in self-rated interest, perceived relevance of video content, and perceived learning from the videos (all $p>0.05$; see Figure 1, B and C).

Before the beginning of this study, participants were asked to what extent they preferred lessons to include "just the facts" versus also including interesting, but irrelevant anecdotes. Responses to this item were split fairly evenly, with $54.5 \%$ of students indicating a moderate to strong preference for seductive details versus $43.3 \%$ of students indicating a moderate to strong preference for lessons without seductive details (Figure $2 \mathrm{~A})$. Very few $(2.2 \%)$ students indicated no preference, suggesting to us that the presence of seductive details can be highly polarizing for students. Therefore, we hypothesized that we might observe varying reactions to video lectures with seductive details based on students' self-reported preferences. However, students' preferences for lesson content did not impact the effect of seductive details on students' video quiz scores, interest in video lectures, or perceived relevance of course material (Figure 2, B-D).
Together, these data suggest that, contrary to previous lab studies, seductive details during video lectures do not have an omnibus negative effect on performance in the context of a large flipped college biology course.

\section{Students with High Self-Reported Prior Knowledge Perceive Greater Learning with Seductive Details}

In previous studies ascribing a harmful effect to the use of seductive details, a common hypothesized mechanism of the effect is that including interesting but irrelevant examples and stories increases the cognitive load experienced by the learner. This in turn decreases the amount of working memory available for learners to use in learning relevant course material, potentially leading to decreased learning. Recent studies have suggested that prior knowledge can mitigate the negative effect of seductive details in the laboratory learning environment by decreasing the overall cognitive load experienced by the learner (Wang and Adesope, 2016; Fries et al., 2019).

To determine whether prior knowledge moderated the effect of seductive details in the classroom, we binned students into low and high prior knowledge groups based on a median split of self-reported precourse ability to achieve a course learning outcome for each of the eight class sessions with seductive details. Students with low self-reported prior knowledge 
A.

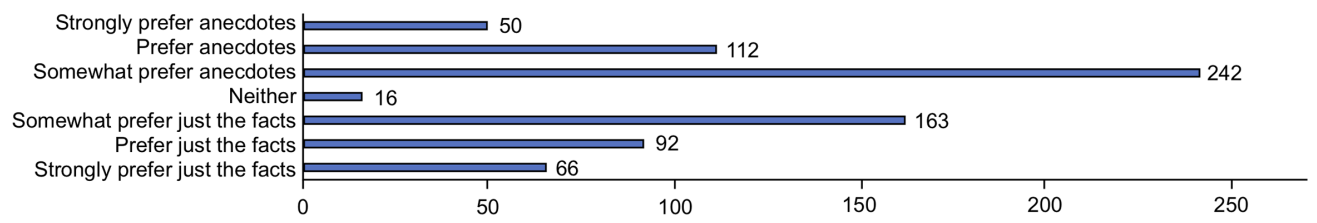

B.

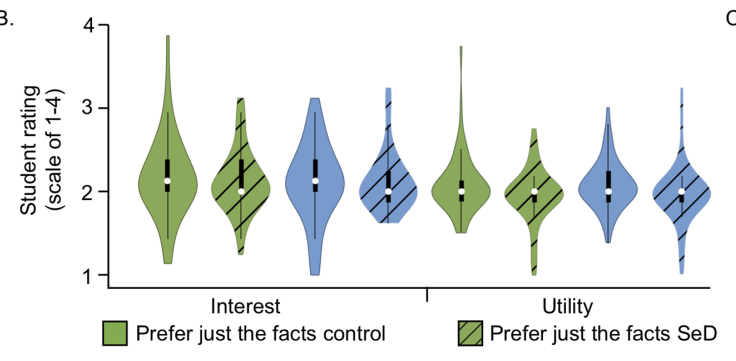

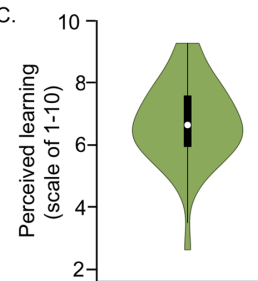
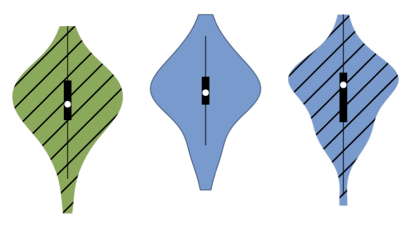

Prefer anecdotes control $\triangle$ Prefer anecdotes SeD

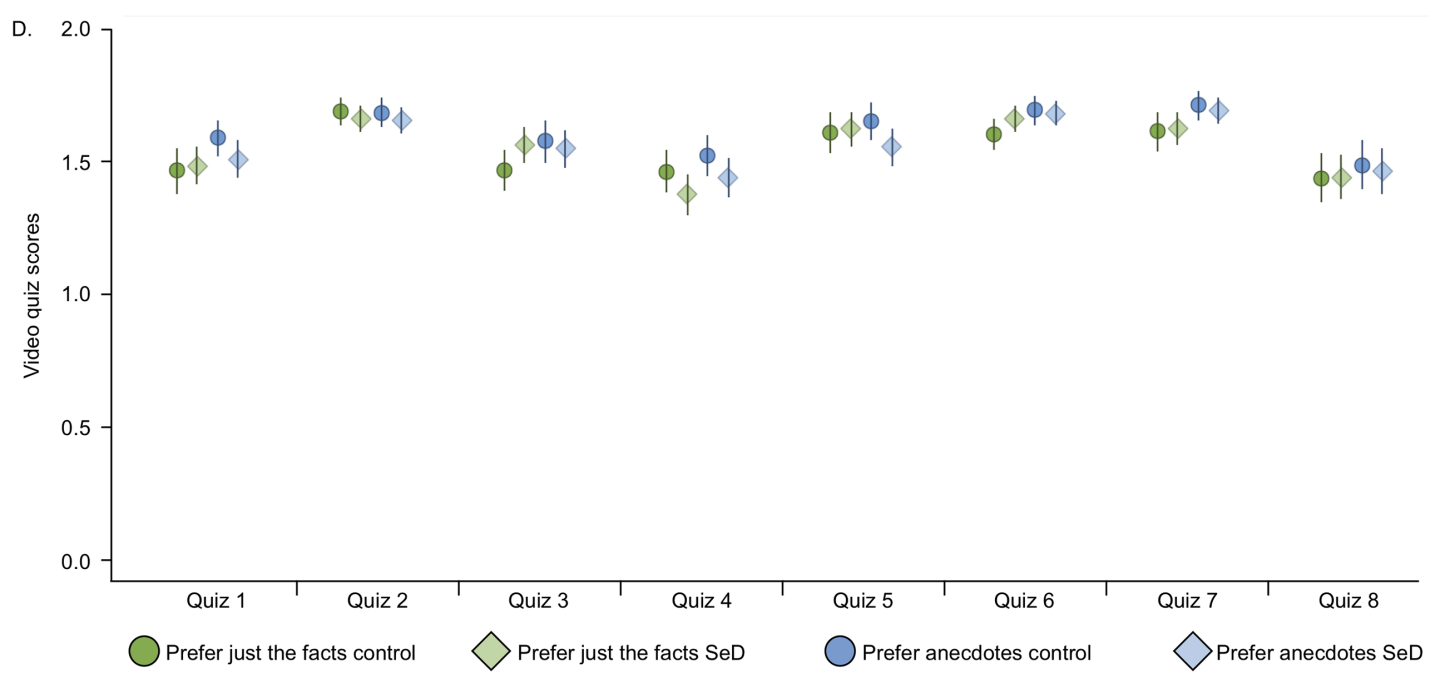

FIGURE 2. (A) Student preferences for lessons that include "just the facts" vs. lessons that include interesting but irrelevant anecdotes. (B) Violin plots of reported interest in video lectures and perceived relevance of video lecture material to students' lives or future plans. (C) Violin plots of average self-reported perceptions of learning from video lectures. (D) Average video quiz scores for each lesson. Dots indicate mean score for each quiz; whiskers indicate the $95 \%$ confidence interval. $n=127,147,114,149,128,146,114,147,128,147,117$, $147,128,151,116,147,124,147,113,149,124,149,115,146,128,149,112,146,124,142,114,142$ sample points. SeD, seductive details.

appeared unaffected by seductive details in both quiz performance and affective measures (Table 3). However, students with high self-reported prior knowledge reported higher perceived learning from videos that included seductive details than control videos (Table 3 and Figure 3).

Despite a large effect size in this perceived learning measure (eta-squared $=0.06$ ), these students did not view the videos with seductive details as any more interesting or relevant than control videos. The increase in perceived learning among students with high self-reported prior knowledge did not translate to immediate significant differences in performance on video quizzes and exams meant to test knowledge retention or overall course grade compared with similar students who were not presented with seductive details (Table 4). In fact, students with high self-reported prior knowledge performed similarly to students with low self-reported prior knowledge on all graded course items, regardless of whether or not they were presented with seductive details (Supplemental Tables S4 and S5).
Perceived Learning Is Enhanced by Seductive Details for Non-First Generation and Non-Underrepresented Students One rationale commonly cited by instructors for including seductive details in their course content is to increase the utility value or perceived relevance of course material. In particular, students who are first-generation or underrepresented are disproportionately likely to view course content in introductory STEM classes as irrelevant to their own lives or community values, potentially leading to a higher attrition rate for these students in STEM majors (Harackiewicz et al., 2016). Therefore, we asked whether the seductive detail effect observed for students with high prior knowledge differed between first-generation or underrepresented students and other students. We hypothesized that these students would be more likely to experience enhanced utility value in response to videos with seductive details.

Overall, first-generation and underrepresented students did not indicate any effect of seductive details on video interest, relevance, or perceived learning, and those who were presented seductive details did not perform differently on video quizzes. 
TABLE 3. Video quiz scores, interest, relevance, and perceived learning by self-reported prior knowledge and seductive detail (SeD) group ${ }^{\mathrm{a}}$

\begin{tabular}{|c|c|c|c|c|c|c|}
\hline & \multicolumn{3}{|c|}{ Low prior knowledge } & \multicolumn{3}{|c|}{ High prior knowledge } \\
\hline & Control & SeD & $p$ value & Control & SeD & $p$ value \\
\hline Video quiz score & 1.67 & 1.66 & 0.741 & 1.65 & 1.71 & 0.100 \\
\hline Video interest & 2.48 & 2.52 & 0.566 & 2.36 & 2.44 & 0.451 \\
\hline Perceived relevance & 2.51 & 2.54 & 0.732 & 2.42 & 2.44 & 0.852 \\
\hline Perceived learning & 6.93 & 6.91 & 0.889 & 7.05 & 7.67 & $0.011 *$ \\
\hline
\end{tabular}

aSignificance determined by independent-samples $t$ test. Significant $p$ value $(p<0.05)$ denoted with an asterisk. $N=754$.

First-generation students who were presented with seductive details did perform significantly better on their first midterm exam, suggesting that seductive details may have the potential to impact learning, specifically over a longer term, for certain groups of students (Supplemental Table S3).

When we disaggregated students into low and high prior knowledge groups, we found that, although perceived learning increases with seductive details for students with high prior knowledge as a whole, this effect is only significant in non-first generation and non-underrepresented students (Table 5). Among students with low self-reported prior knowledge, seductive details failed to impact students whether or not they were first-generation or underrepresented (Table 6).

\section{Seductive Details Are Memorable}

The data demonstrate that, despite the fact that the addition of seductive details did not lead to measurable gains in course learning goals as measured by quizzes, exams, and course performance, students with high prior knowledge reported learning more from videos when the videos included seductive details. We wondered whether this increase in perceived learning represented an actual increase in learning that was not measured by the student learning outcomes (i.e., postvideo quizzes) but reflected information that students would nevertheless remember and consider relevant to their learning. During the last week of instruction, when asked which topics from the video lectures they would be most likely to remember in 5 years, $16.3 \%$ of students in the seductive detail group mentioned one

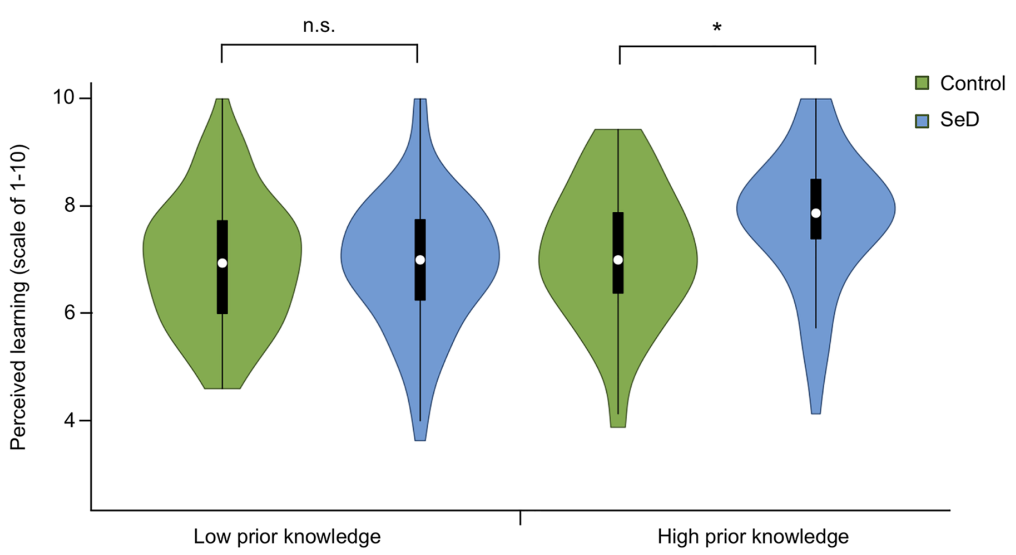

FIGURE 3. Violin plots showing perceptions of learning in students with low vs. high levels of self-reported prior knowledge. White circles show the medians; box limits indicate the 25th and 75th percentiles as determined by R software; whiskers extend 1.5 times the interquartile range from the 25 th and 75 th percentiles; polygons represent density estimates of data and extend to extreme values. Significant differences $(p<0.05)$ are denoted with an asterisk. SeD, seductive details. n.s., not significant; ${ }^{*}, p=0.006$ or more seductive details that they would be likely to remember without any specific prompting, despite seductive details making up a small proportion of their video lectures (a total of 17 minutes and 13 seconds out of almost 8 hours of video content) for the initial 4 weeks of the course only, and never being tested on or brought up subsequently. This indicates to us that students considered these tangential topics to be salient and memorable. We therefore hypothesized that the observed increase in perceived learning among high prior knowledge students might represent a perceived increase in learning of material not related to student learning outcomes.

In a postcourse survey given during the final week of instruction, a group of students in the seductive details condition was asked to "Take a moment to try and recall everything you can remember about the L'Oreal True Tone example that was provided as a part of a previous video lesson." This anecdote about a new line of makeup products by L'Oreal meant to better reflect variation in human skin tones was presented during the first week of the course. Student responses were coded into one of four categories: 1) student was unable to recall anything about the anecdote; 2) student was able to recall just the anecdote given, without any connection to a genetics concept with which it was associated; 3) student recalled just the linked genetic concept without any recall of the anecdote; or 4) student recalled the anecdote and the linked genetic concept. We found that students with high self-reported prior knowledge outperformed students with low self-reported prior knowledge in recalling relevant concept information associated with seductive details (Figure 4, A and B).

While only $27.7 \%$ of low prior knowledge students were able to recall anything about the seductive detail and/or the associated concept, $42.2 \%$ of the high prior knowledge students accurately recalled details of the seductive detail and/or the associated concept. Taking a closer look, we find that $33.3 \%$ of the high prior knowledge students recalled the seductive detail specifically compared with $18.5 \%$ for the low prior knowledge students. Furthermore, recall of seductive details appeared to be significantly correlated with greater perceived learning from video lectures (linear-by-linear association, $p=$ 0.038; Figure 4C). These data suggest that the increase in perceived learning from videos with seductive details may indeed reflect an actual increase in learning in domains unrelated to student learning outcomes for the course. 
TABLE 4. Midterm 1 scores, final exam scores, and final course percentage by self-reported prior knowledge and seductive detail (SeD) group $^{a}$

\begin{tabular}{|c|c|c|c|c|c|c|c|c|c|}
\hline & \multicolumn{3}{|c|}{ Low prior knowledge } & \multicolumn{3}{|c|}{ High prior knowledge } & \multicolumn{3}{|c|}{ Overall } \\
\hline & Control & SeD & $p$ value & Control & SeD & $p$ value & Control & SeD & $p$ value \\
\hline Midterm 1 score & 74.08 & 75.60 & 0.355 & 75.58 & 75.99 & 0.840 & 74.66 & 75.76 & 0.389 \\
\hline Final course percentage & 84.51 & 85.25 & 0.510 & 85.13 & 84.76 & 0.798 & 84.75 & 85.05 & 0.730 \\
\hline
\end{tabular}

aSignificance determined by independent-samples $t$ test. $N=754$.

\section{DISCUSSION}

Overall, our data suggest that the inclusion of seductive details in video lectures does not harm undergraduate student learning in the context of a large flipped introductory genetics course. These results appear to differ from the reported negative impact of seductive details on student learning in the educational psychology literature and are more consistent with research suggesting that it is students with high working memory and prior knowledge that most benefit from the inclusion of seductive details (Sanchez and Wiley, 2006; Park et al., 2011, 2015b; Sitzmann and Johnson, 2014).

Unlike previous research into the impact of seductive details on student learning and memory, our study has the advantage of having a large sample size and taking place in an authentic learning context. Therefore, our findings are likely to be relevant in the blended learning environments that are becoming increasingly common at large research universities. Our main results suggest that instructors concerned about derailing student learning with the use of seductive details need not worry, as the inclusion of seductive details had no negative impact on student learning.

Contrary to our initial hypotheses and previous reports, the inclusion of seductive details did not impact student learning for most groups of students either positively or negatively as measured by course performance. We did observe an increase in midterm exam scores for first-generation students, indicating that the presence of seductive details may have a positive impact on learning over a medium- to long-term period for specific subsets of students.

Given our observed increase in perceived learning when students were provided seductive details, we wondered why these details did not increase actual learning. One possibility is that the seductive details included in this study were not interesting enough to capture students' attention and trigger associations between tangential "real-world" examples and course content. However, we have reason to believe that students did indeed find the included seductive details to be interesting. Despite seductive details only making up a total of 17 minutes out of almost 8 hours of total video content for the first 4 weeks of the course, when asked at the end of the 10-week course what topics they considered to be the most memorable from the course, a significant number of students mentioned seductive details that had not been referenced again in the course since the first week. Additionally, the high level of recall observed for seductive details presented early in the quarter suggests that the details presented were memorable and interesting.

While we did not find that seductive details directly increase actual performance outcomes on summative assessments for most students, our results open the door for other possible mechanisms for learning. For instance, research in memory suggests that retrieval improves when content is associated with diverse and highly distinctive retrieval cues (Anderson, 1983; Uitvlugt and Healey, 2019). Hence, to the extent that seductive

TABLE 5. Video quiz scores, interest, perceived relevance, and perceived learning by first-generation (FG) status and underrepresented minority (URM) status in students with high self-reported prior knowledge ${ }^{a}$

\begin{tabular}{|c|c|c|c|c|c|c|c|c|}
\hline & \multicolumn{2}{|c|}{ Non-FG $(n=194)$} & \multicolumn{2}{|c|}{ FG $(n=98)$} & \multicolumn{2}{|c|}{ Non-URM $(n=243)$} & \multicolumn{2}{|c|}{ URM $(n=52)$} \\
\hline & Control & SeD & Control & SeD & Control & SeD & Control & SeD \\
\hline Video quiz score & 1.66 & 1.72 & 1.65 & 1.70 & 1.66 & 1.73 & 1.59 & 1.62 \\
\hline Perceived relevance & 2.24 & 2.24 & 2.72 & 2.68 & 2.48 & 2.47 & 2.20 & 2.28 \\
\hline Perceived learning & 7.05 & $7.87^{*}$ & 7.00 & 7.49 & 7.05 & $7.70 * *$ & 6.95 & 7.66 \\
\hline
\end{tabular}

aSignificance determined by independent-samples t test, values that are significantly different from control group values $(p<0.05)$ are denoted with an asterisk $(*)$ or double asterisk $\left.{ }^{* *}\right) . N=295$. SeD, seductive details.

* $p=0.015$.

$* * p=0.019$.

TABLE 6. Video quiz scores, interest, perceived relevance, and perceived learning by first-generation (FG) status and underrepresented minority (URM) status in students with low self-reported prior knowledge $\mathrm{a}^{\mathrm{a}}$

\begin{tabular}{|c|c|c|c|c|c|c|c|c|}
\hline & \multicolumn{2}{|c|}{ Non-FG $(n=261)$} & \multicolumn{2}{|c|}{$\mathrm{FG}(n=178)$} & \multicolumn{2}{|c|}{ Non-URM $(n=353)$} & \multicolumn{2}{|c|}{ URM $(n=94)$} \\
\hline & Control & SeD & Control & SeD & Control & SeD & Control & SeD \\
\hline Video quiz score & 1.68 & 1.68 & 1.67 & 1.65 & 1.72 & 1.70 & 1.51 & 1.53 \\
\hline Video interest & 2.37 & 2.44 & 2.64 & 2.61 & 2.49 & 2.54 & 2.48 & 2.46 \\
\hline Perceived relevance & 2.38 & 2.47 & 2.67 & 2.62 & 2.45 & 2.52 & 2.72 & 2.63 \\
\hline Perceived learning & 6.89 & 6.87 & 7.01 & 6.86 & 6.91 & 6.86 & 7.07 & 7.04 \\
\hline
\end{tabular}

aSignificance determined by independent-samples $t$ test. $N=447$. SeD, seductive details. 
A. Low prior knowledge

B High prior knowledge
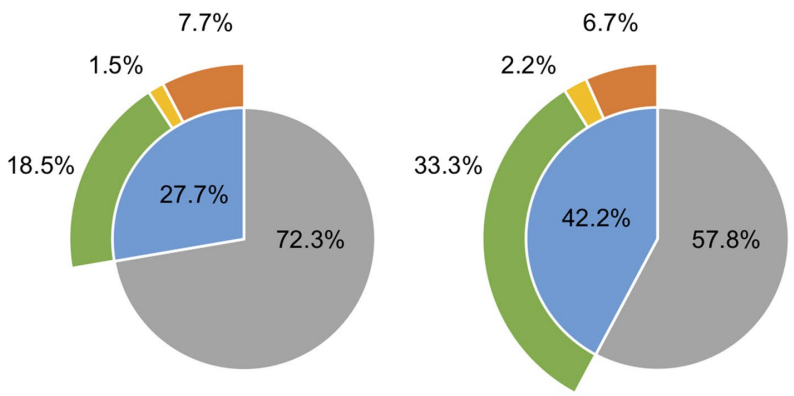

C.

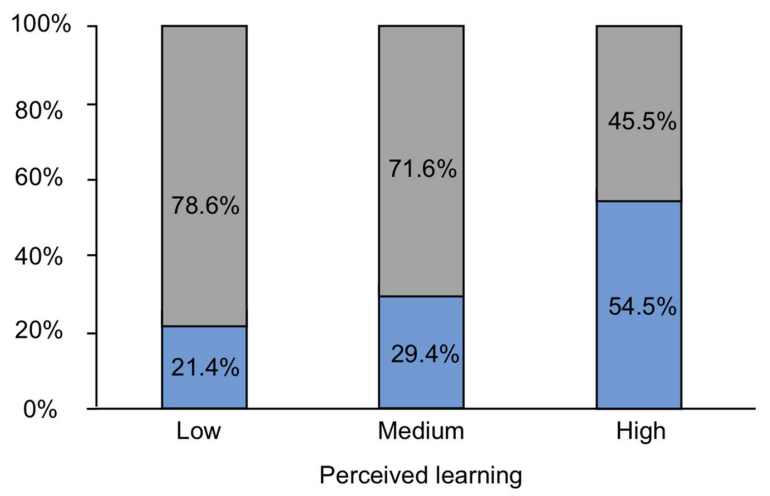

$\square$ No SeD recall
$\square$ Accurate SeD recall
$\square$ Recall of anecdote
$\square$ Recall of genetic concept
$\square$ Recall of anecdote and genetic concept

FIGURE 4. Seductive detail (SeD) recall accuracy for students with low self-reported prior knowledge (A) and high self-reported prior knowledge (B). Inner circle of sunburst plot indicates the number of students who recalled the seductive detail example (blue, recall; gray, no recall). Outer circle indicates the extent to which students recalled the example given (green, anecdote recalled; yellow, genetics concept recalled; orange, anecdote and genetics concept recalled). (C) Percent of students who recalled details of the seductive detail example given based on their self-reported level of learning from the video lessons (self-reported learning was categorized based on a tercile split of average perceived learning levels). Blue, accurate recall of seductive detail; gray, no recall or inaccurate recall of seductive detail.

details are well remembered by students, they may provide a retrieval cue that might not otherwise exist for many students.

It is also important to highlight that seductive details may provide additional value in terms of helping to smooth out a path for students to connect with their instructors. A factor not often discussed in learning sciences research is the importance of professors building warm relationships with students (Christe, 2013). Seductive details may be one way to show students that professors are relatable and have a sense of humor, which could create an entry point for students to feel more comfortable attending office hours, asking questions after class, and engaging in more meaningful interactions with instructors (Cooper et al., 2018). This potential effect would not be evident in the results of the study described here, as the seductive details were presented by a different instructor than the primary course instructor. Nevertheless, they could help humanize the life sciences domain.

Our findings represent an important step toward understanding how seductive details affect students in the organic environment of a large flipped undergraduate science course. Future expansions on this line of work should investigate the possibility that different modes of seductive details (e.g., auditory, visual, or text based) might affect students in different ways. Additionally, recent utility-value interventions have found that students respond more robustly to self-generated real-world examples than to instructor-provided examples (Harackiewicz et al., 2016), and this self-generation effect may extend to students' responses to seductive details associated with course content-it is possible that students might exhibit a greater response to self-generated real-world stories that tangentially connect to topics in life sciences courses. Despite the need for continued investigation into the effect of varying presentations of seductive details in the classroom, this study represents an important step forward in understanding the impacts of a long-derided but often-employed technique in a genuine classroom environment.

\section{ACKNOWLEDGMENTS}

Thanks to Dr. Hung Pham, the primary instructor of LS 4: Genetics at the University of California, Los Angeles, during this study, whose enthusiastic support made this effort possible. We acknowledge support from the Life Sciences Core Curriculum Department at UCLA and the Department of Psychology at UCLA. This research study was supported, in part, by a grant to UCLA from the National Science Foundation's Improving Undergraduate STEM Education program (DUE award no. 1432804).

\section{REFERENCES}

Ainley, M., Hidi, S., \& Berndorff, D. (2002). Interest, learning, and the psychological processes that mediate their relationship. Journal of Educational Psychology, 94(3), 545-561. https://doi.org/10.1037/0022-0663.94.3.545

Anderson, J. R. (1983). A spreading activation theory of memory. Journal of Verbal Learning and Verbal Behavior, 22(3), 261-295. https://doi .org/10.1016/S0022-5371(83)90201-3

Arcand, K., Watzke, M., Smith, L. F., \& Smith, J. (2010). Surveying Aesthetics \& Astronomy: A project exploring the public's perception of astronomical images and the science within. Communicating Astronomy with the Public Journal, 10, 13-16.

Arfield, J., Hodgkinson, K., Smith, A., \& Wade, W. (2013). Flexible learning in higher education. Florence, KY: Taylor and Francis.

Belland, B. R., Kim, C., \& Hannafin, M. J. (2013). A framework for designing scaffolds that improve motivation and cognition. Educational Psychologist, 48(4), 243-270. https://doi.org/10.1080/00461520.2013.838920

Berlyne, D. E. (1970). Novelty, complexity, and hedonic value. Perception \& Psychophysics, 8(5), 279-286. https://doi.org/10.3758/BF03212593

Bloom, B. S., Englehart, M. D., First, E. D., Hill, W. H., \& Krathwohl, D. R. (1956) Taxonomy of educational objectives: The classification of educational goals. Handbook I: The cognitive domain. New York: David McKay.

Canning, E. A., \& Harackiewicz, J. M. (2015). Teach it, don't preach it: The differential effects of directly-communicated and self-generated utility value information. Motivation Science, 1(1), 47-71. https://doi. org/10.1037/mot0000015

Casad, B. J., Oyler, D. L., Sullivan, E. T., McClellan, E. M., Tierney, D. N., Anderson, D. A., ... \& Flammang, B. J. (2018). Wise psychological interventions to improve gender and racial equality in STEM. Group Processes \& Intergroup Relations, 21(5), 767-787. https://doi.org/10.1177/1368430218767034

Christe, B. (2013). The importance of faculty-student connections in STEM disciplines: A literature review. Journal of STEM Education: Innovations and Research, 14(3), 22 
Cooper, K. M., Hendrix, T., Stephens, M. D., Cala, J. M., Mahrer, K., Krieg, A., ... \& Brownell, S. E. (2018). To be funny or not to be funny: Gender differences in student perceptions of instructor humor in college science courses. PLOS ONE, 13(8), e0201258. https://doi.org/10.1371/journal.pone.0201258

Cromley, J. G., Perez, T., \& Kaplan, A. (2016). Undergraduate STEM achievement and retention: Cognitive, motivational, and institutional factors and solutions. Policy Insights from the Behavioral and Brain Sciences, 3(1), 4-11.

Dewey, J. (1913). Interest and effort in education. Boston: Houghton Mifflin. https://doi.org/10.1037/14633-000

Downs, V. C., Javidi, M. M., \& Nussbaum, J. F. (1988). An analysis of teachers verbal communication within the college classroom: Use of humor, self-disclosure, and narratives. Communication Education, 37(2), 127141. https://doi.org/10.1080/03634528809378710

Eccles, J., Adler, T. F., Futterman, R., Goff, S. B., Kaczala, C., \& Meece, J. L. (1983). Expectancies, values, and academic behaviors. In Spence, J. T. (Ed.), Achievement and achievement motives: Psychological and sociological approaches (pp. 75-146). San Francisco: Freeman.

Freeman, S., Eddy, S. L., McDonough, M., Smith, M. K., Okoroafor, N., Jordt, H., \& Wenderoth, M. P. (2014). Active learning increases student performance in science, engineering, and mathematics. Proceedings of the National Academy of Sciences USA, 111(23), 8410-8415. https://doi org/10.1073/pnas.1319030111

Fries, L., DeCaro, M. S., \& Ramirez, G. (2019). The lure of seductive details during lecture learning. Journal of Educational Psychology, 111(4), 736 749. https://doi.org/10.1037/edu0000301

Garrison, D. R., \& Kanuka, H. (2004). Blended learning: Uncovering its transformative potential in higher education. The Internet and Higher Education, 7(2), 95-105. https://doi.org/10.1016/j.iheduc.2004.02.001

Harackiewicz, J. M., Canning, E. A., Tibbetts, Y., Priniski, S. J., \& Hyde, J. S. (2016). Closing achievement gaps with a utility-value intervention: Disentangling race and social class. Journal of Personality and Social Psychology, 111(5), 745.

Harackiewicz, J. M., Durik, A. M., Barron, K. E., Linnenbrink-Garcia, L., \& Tauer, J. M. (2008). The role of achievement goals in the development of interest: Reciprocal relations between achievement goals, interest, and performance. Journal of Educational Psychology, 100(1), 105-122. https://doi.org/10.1037/0022-0663.100.1.105

Harp, S. F., \& Maslich, A. A. (2005). The consequences of including seductive details during lecture. Teaching of Psychology, 32(2), 100-103. https:// doi.org/10.1207/s15328023top3202_4

Harp, S. F., \& Mayer, R. E. (1998). How seductive details do their damage: A theory of cognitive interest in science learning. Journal of Educational Psychology, 90(3), 414-434. https://doi.org/10.1037/0022-0663.90.3.414

Hidi, S., \& Renninger, K. A. (2006). The four-phase model of interest development. Educational Psychologist, 41(2), 111-127. https://doi.org/10.1207/ s15326985ep4102_4

Hughes, B. E. (2018). Coming out in STEM: Factors affecting retention of sexual minority STEM students. Science Advances, 4(3), eaao6373. https://doi.org/10.1126/sciadv.aao6373

Hulleman, C. S., Godes, O., Hendricks, B. L., \& Harackiewicz, J. M. (2010). Enhancing interest and performance with a utility value intervention. Journal of Educational Psychology, 102(4), 880-895. https://doi .org/10.1037/a0019506

Hulleman, C. S., \& Harackiewicz, J. M. (2009). Promoting interest and performance in high school science classes. Science, 326(5958), 1410-1412.

Hurtado, S., Newman, C. B., Tran, M. C., \& Chang, M. J. (2010). Improving the rate of success for underrepresented racial minorities in STEM fields: Insights from a national project. New Directions for Institutional Research, 2010(148), 5-15. https://doi.org/10.1002/ir.357

Johnson, L., Adams Becker, S., Estrada, V., \& Freeman, A. (2015). NMC Horizon report: 2015 Higher education edition. Austin, TX: New Media Consortium. Retrieved June 1, 2018, from http://cdn.nmc.org/ media/2015-nmc-horizon-report-HE-EN.pdf

Karabenick, S., \& Urdan, T. C. (Eds.). (2014). Motivational interventions. Bingley, England: Emerald Group Publishing.

Mayer, R. E., Griffith, E., Jurkowitz, I. T. N., \& Rothman, D. (2008). Increased interestingness of extraneous details in a multimedia science presenta- tion leads to decreased learning. Journal of Experimental Psychology: Applied, 14(4), 329-339. https://doi.org/10.1037/a0013835

Mitchell, G. (2012). Revisiting truth or triviality: The external validity of research in the psychological laboratory. Perspectives on Psychological Science, 7(2), 109-117. https://doi.org/10.1177/1745691611432343

Palmer, D. H. (2009). Student interest generated during an inquiry skills lesson. Journal of Research in Science Teaching, 46(2), 147-165. https:// doi.org/10.1002/tea.20263

Park, B., Flowerday, T., \& Brünken, R. (2015a). Cognitive and affective effects of seductive details in multimedia learning. Computers in Human Behavior, 44, 267-278. https://doi.org/10.1016/j.chb.2014.10.061

Park, B., Korbach, A., \& Brünken, R. (2015b). Do learner characteristics moderate the seductive-details-effect? A cognitive-load-study using eye-tracking. Journal of Educational Technology \& Society, 18(4), 24-36.

Park, B., Moreno, R., Seufert, T., \& Brünken, R. (2011). Does cognitive load moderate the seductive details effect? A multimedia study. Computers in Human Behavior, 27(1), 5-10. https://doi.org/10.1016/j.chb.2010.05.006

President's Council of Advisors on Science and Technology. (2012). Engage to excel: Producing one million additional college graduates with degrees in science, technology, engineering, and mathematics. Washington, DC: U.S. Government Office of Science and Technology.

Rey, G. D. (2012). A review of research and a meta-analysis of the seductive detail effect. Educational Research Review, 7(3), 216-237. https://doi. org/10.1016/j.edurev.2012.05.003

Sanchez, C. A., \& Wiley, J. (2006). An examination of the seductive details effect in terms of working memory capacity. Memory \& Cognition, 34(2), 344-355. https://doi.org/10.3758/BF03193412

Sarıtepeci, M., \& Çakır, H. (2015). The effect of blended learning environments on student motivation and student engagement: A study on social studies course. TED Eğitim ve Bilim, 40(177). https://doi.org/10.15390/ EB.2015.2592

Sitzmann, T., \& Johnson, S. (2014). The paradox of seduction by irrelevant details: How irrelevant information helps and hinders self-regulated learning. Learning and Individual Differences, 34, 1-11. https://doi .org/10.1016/j.lindif.2014.05.009

Sork, V., Hurtado, S., Sanders, E., Wahl, K., \& Teel, T. (2015, December). Enhancing student success and building inclusive classrooms at UCLA (Report to the executive vice chancellor and provost). Retrieved November 7, 2018, from https://ceils.ucla.edu/wp-content/uploads/ sites/2/2016/11/Enhancing-Student-Success-Building-Inclusive -Classrooms-at-UCLA-Report_December-2015-Hurdado-Sork-Report .pdf

Spitzer, M., Wildenhain, J., Rappsilber, J., \& Tyers, M. (2014). BoxPlotR: A Web tool for generation of box plots. Nature Methods, 11, 121.

Stahl, A. E., \& Feigenson, L. (2015). Observing the unexpected enhances infants' learning and exploration. Science, 348(6230), 91-94. https:// doi.org/10.1126/science.aaa3799

Stigler, J. W., \& Givvin, K. B. (2017). Online learning as a wind tunnel for improving teaching. New Directions for Evaluation, 2017(153), 79-91. https://doi.org/10.1002/ev.20232

Uitvlugt, M. G., \& Healey, M. K. (2019). Temporal proximity links unrelated news events in memory. Psychological Science, 30(1), 92-104. https:// doi.org/10.1177/0956797618808474

Valdesolo, P., Shtulman, A., \& Baron, A. S. (2017). Science is awe-some: The emotional antecedents of science learning. Emotion Review, 9(3), 215221. https://doi.org/10.1177/1754073916673212

Wang, Z., \& Adesope, O. (2016). Does learners' prior knowledge moderate the detrimental effects of seductive details in reading from text? A 2 by 3 study. International Journal of Instruction, 9(2), 35-50. https:// doi.org/10.12973/iji.2016.923a

Yue, C. L., \& Bjork, E. L. (2017). Using selective redundancy to eliminate the seductive details effect: Eliminating the seductive details effect. Applied Cognitive Psychology, 31(5), 565-571. https://doi.org/10.1002/acp.3348

Zusho, A., Pintrich, P. R., \& Coppola, B. (2003). Skill and will: The role of motivation and cognition in the learning of college chemistry. International Journal of Science Education, 25(9), 1081-1094. https://doi .org/10.1080/0950069032000052207 